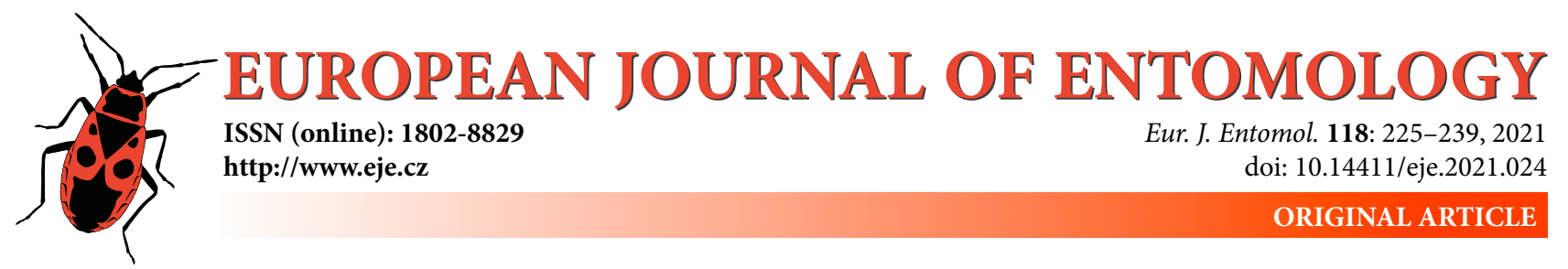

\title{
Taxonomic notes on the tribe Ectinoderini (Hemiptera: Heteroptera: Reduviidae: Harpactorinae) from the Indochinese Peninsula
}

\author{
Zhuo CHEN ${ }^{1}$ iD, VALÉRIe A. LEMAîTRE ${ }^{2}$ (D) and WANZH CAI ${ }^{1, *}$ (D) \\ ${ }^{1}$ Department of Entomology and MOA Key Lab of Pest Monitoring and Green Management, College of Plant Protection, \\ China Agricultural University, Yuanmingyuan West Road, Beijing 100193, China; e-mails: insectchen625@126.com, \\ caiwz@cau.edu.cn \\ ${ }^{2}$ Department of Life Sciences (Insects), The Natural History Museum, Cromwell Road, London SW7 5BD, U.K.; \\ e-mail: v.lemaitre@nhm.ac.uk
}

\begin{abstract}
Key words. Hemiptera, Heteroptera, Reduviidae, Harpactorinae, Ectinoderini, Amulius, Ectinoderus, Parapanthous, taxonomy, new synonymy, new combination, Oriental Region

Abstract. The identities of two species of assassin bugs in the tribe Ectinoderini (Hemiptera: Heteroptera: Reduviidae: Harpactorinae) from the Indochinese Peninsula are reviewed, resulting in the following new synonymy and new combinations: Amulius Stål, $1865=$ Parapanthous Distant, 1919, syn. n.; Amulius spinicollis (Distant, 1919), comb. n. (transferred from Parapanthous) and Ectinoderus confragosus (Distant, 1919), comb. n. (transferred from Amulius). Lectotypes of these species are designated. The hemelytral venations of Amulius and Ectinoderus Westwood, 1843 are briefly discussed and their diagnoses accordingly revised. Amulius is newly reported from Vietnam and Ectinoderus is recorded from Cambodia for the first time.
\end{abstract}

ZooBank Article Registration: http://zoobank.org/urn:Isid:zoobank.org:pub:BE2F1E95-52A7-4C96-8C92-4021C3DA224C

\section{INTRODUCTION}

Members of the Oriental and Pacific assassin bug tribe Ectinoderini (Hemiptera: Heteroptera: Reduviidae: Harpactorinae) are noteworthy for applying sticky plant resins to their fore legs to help them catch their prey (Schuh \& Weirauch, 2020). Twenty species in two genera (Amulius Stål, 1865 and Ectinoderus Westwood, 1843, each with ten species) belong to this tribe (Maldonado-Capriles, 1990). The species are robust, somewhat dorsoventrally flattened bugs, usually colourfully patterned, and can be distinguished from other harpactorines by the following characters: ocelli lateral and more widely separated than eyes; labium short and straight, reaching or slightly surpassing anterior margin of prosternum; pronotum strongly expanded posteriorly, leaving apex of scutellum exposed; prosternal groove nonstriated; fore tarsus not segmented; membrane of hemelytron with three cells (Davis, 1969; Cai et al., 1994).

The group based on Ectinoderus was first proposed by Stål (1859) as "Ectinoderida". It was regarded as a distinct subfamily of Reduviidae or included in the Apiomerinae (now Apiomerini of Harpactorinae), but more recently considered a tribe of Harpactorinae based on a morphological phylogeny of the Harpactoroid Complex (Davis, 1969). Our knowledge concerning Ectinoderini is still very scarce due to a limitation of samples and for this reason its monophyly was not tested in two recent phylogenetic studies of Reduviidae, though their conclusions provided more phylogenetic context for the group (Weirauch, 2008a; Zhang et al., 2016). In addition, the concept of Ectinoderini is inconsistently applied in various works, and some (e.g., Miller, 1956, 1971; Davis, 1969; Hsiao \& Ren, 1981) also include the genus Parapanthous Distant, 1919 in this tribe. All species currently included in this tribe were described before the 1960s and most of them are only known from original descriptions that are inadequate and usually lacking illustrations, therefore modern taxonomic revisions of these species are required.

The present study reviews the identities of Amulius confragosus Distant, 1919 and Parapanthous spinicollis Distant, 1919 and results in the proposal of a new generic synonymy and two new combinations. Lectotypes are designated for the two species. A brief discussion of some characters of the hemelytral venation which could be used

\footnotetext{
* Corresponding author; e-mail: caiwz@cau.edu.cn
} 
as genus-level diagnostic characters is carried out, and the diagnoses of Amulius and Ectinoderus are accordingly modified.

\section{MATERIAL AND METHODS}

Label data of type specimens are copied verbatim in quotation marks (" "); lines on the same label are separated by a backslash (\), different labels are separated by a semicolon (;), and comments on label data are provided in square brackets ([ ]); printed (pr.) and handwritten (hw.) texts are indicated. Abbreviations for depositories: BMNH - Natural History Museum, London, U.K.; CAU - Entomological Museum of China Agricultural University, Beijing, China; MZH - Finnish Museum of Natural History, Helsinki, Finland; OUMNH - Oxford University Museum of Natural History, Oxford, U.K.; RBINS - Royal Belgian Institute of Natural Sciences, Brussels, Belgium.

Male genitalia were soaked in hot $20 \%$ lactic acid solution for approximately ten minutes to remove soft tissue, rinsed in distilled water and dissected under a Motic binocular dissecting microscope. Dissected genitalia were placed in a vial containing glycerine and, after examination, pinned under the corresponding specimen.

Photographs were taken using a Canon 7D Mark II digital camera with a Canon micro lens EF $100 \mathrm{~mm}$ and MP-E $65 \mathrm{~mm}$ for habitus, and an Olympus BX51 microscope for dissected body parts. Helicon Focus version 5.3 was used for image stacking. Figures were assembled using Adobe Photoshop CC 2015. Although the copyright is with the Trustees of the Natural History Museum, London, photographs of BMNH specimens may be used under a Creative Commons Attribution-NonCommercialShareAlike 4.0 (CC BY-NC-SA 4.0) international license. Photographs of specimens from other institutions remain the copyright of these institutions.

The distribution map was built using the online version of SimpleMappr (Shorthouse, 2010). Coordinates were inferred by looking up the names of the localities on the data labels on Mapcarta (https://mapcarta.com/).

Measurements were obtained using a calibrated micrometer. Morphological terminology mainly follows Weirauch (2008a) and Schuh \& Weirauch (2020). The length of the head and that of the postocular part include the collum; the visible labial segments are numbered from II to IV because the first segment is lost or fused into the head capsule in most Reduviidae (Weirauch, 2008b; Schuh et al., 2009).

\section{TAXONOMY}

\section{Genus Amulius Stål, 1865}

Amulius Stål, 1865: 99. Type species: Ectinoderus quadripunctatus Stål, 1859 (by subsequent monotypy: Stål, 1866: 165).

Parapanthous Distant, 1919a: 211. Type species: Parapanthous spinicollis Distant, 1919 (by monotypy). New subjective synonym.

Amulius: Stål, 1866: 165 (listed, type species); Stål, 1867: 245 (diagnosis, catalogue); Walker, 1873a: 69 (in key); Stål, 1874: 44, 45 (in key, catalogue); Lethierry \& Severin, 1896: 149 (catalogue); Distant, 1904: 326, 327 (in key, redescription, distribution, fauna of India, Sri Lanka and Myanmar); Distant, 1911: 107 (listed); Roepke, 1932: 5 (list of species); Miller, 1938: 750 (listed, biology); China, 1940: 234 (listed, fauna of China); Miller, 1942: 55 (listed, biology); Hoffmann, 1944: 40 (catalogue, fauna of China); Miller, 1956: 113, 114 (listed, biology); Davis, 1969: 87 (listed); Miller, 1971: 136 (listed, biology); Hsiao \& Ren, 1981: 412 (diagnosis, fauna of China); Maldonado-Capriles, 1990: 24 (catalogue); Kerzhner, 1992: 48 (nomenclature); Schuh \& Slater, 1995: 157 (listed); Putshkov \& Putshkov, 1996: 226 (catalogue, Palaearctic); Ambrose, 2006: 2395 (listed); Schuh \& Weirauch, 2020: 354 (listed).

Parapanthous: Miller, 1956: 113, 114 (listed, discussion); Davis, 1969: 87 (listed); Miller, 1971: 136 (listed, discussion); Hsiao \& Ren, 1981: 412 (listed); Maldonado-Capriles, 1990: 252 (catalogue); Ambrose, 2006: 2399 (listed).

Revised diagnosis. Amulius can be distinguished from Ectinoderus by a combination of the following characters: antennal scape distinctly shorter than head, pedicel longest; anterolateral angles of pronotum produced into a pair of long, spine-like processes; hemelytron with $\mathrm{m}$-cu cross vein connecting $\mathrm{M}$ and cubital cell present, cubital cell broad, pentagonal.

Diversity and distribution. This genus currently contains ten species, occurring throughout the Oriental Region to the Malay Archipelago. One species is transferred to, and another one is removed from this genus, therefore the number of species of Amulius remains ten.

Remarks. Stål (1865) separated Amulius from Ectinoderus on the basis of its considerably shorter first antennal segment. He later noticed that these two genera were

Table 1. Information on the species of Amulius and Ectinoderus examined in this study. *

\begin{tabular}{|c|c|c|c|}
\hline Species & Specimen collection data & Type status & Depository \\
\hline A. armillatus Breddin, 1900 & Indonesia: Lampung $(1 \hat{\jmath}, 1$ 우 & - & RBINS \\
\hline A. bipustulatus Bergroth, 1913 & Malaysia: Sarawak (1우) & Syntype & $\mathrm{MZH}$ \\
\hline A. longiceps Stål, 1867 & Indonesia: West Sumatra (1ㅇ) & - & RBINS \\
\hline A. malayus Stål, 1867 & China: Hainan (2ð) & - & CAU \\
\hline Amulius sp. & Indonesia: Riau $(1 \hat{\partial}, 1+)$ & - & RBINS \\
\hline A. spinicollis (Distant, 1919), comb. $\mathrm{n}$. & Vietnam: Son La $(2 \widehat{)})$ & Lectotype ${ }^{* *}$, Paralectotype & BMNH \\
\hline A. viscus Distant, 1911 & Sri Lanka: Sabaragamuwa $(1 \widehat{\partial}, 1$ 우 & Syntype & BMNH \\
\hline E. bipunctatus (Amyot \& Serville, 1843) & Indonesia: Java $(1 \precsim)$ & - & RBINS \\
\hline E. caedens Miller, 1958 & Indonesia: Papua (1ठ) & Paratype & BMNH \\
\hline E. certator Miller, 1958 & Indonesia: West Papua (19) & Paratype & BMNH \\
\hline E. confragosus (Distant, 1919), comb. n. & Laos: Luang Prabang $(1+, 1 \AA)$ & Lectotype $^{* *}$, Paralectotype & BMNH \\
\hline E. exortivus Distant, 1903 & Myanmar: Kayin (1 $\left.{ }^{\lambda}\right)$ & Syntype & BMNH \\
\hline E. Iongimanus Westwood, 1843 (type sp.) & Singapore? $(1 \overbrace{}^{\hat{n}})$ & Syntype & OUMNH \\
\hline E. philippinensis Westwood, 1845 & Philippines (1+9) & Syntype & OUMNH \\
\hline E. sumptuosus Distant, 1903 & Philippines: Dinagat $\left(1{ }^{\lambda}\right)$ & Syntype & BMNH \\
\hline
\end{tabular}

* The hemelytral venation of $A$. sumatranus Roepke, 1932 and $E$. celebensis Miller, 1954 are based on the illustrations of the original descriptions (Roepke, 1932; Miller, 1954). ${ }^{* *}$ Here designated. 

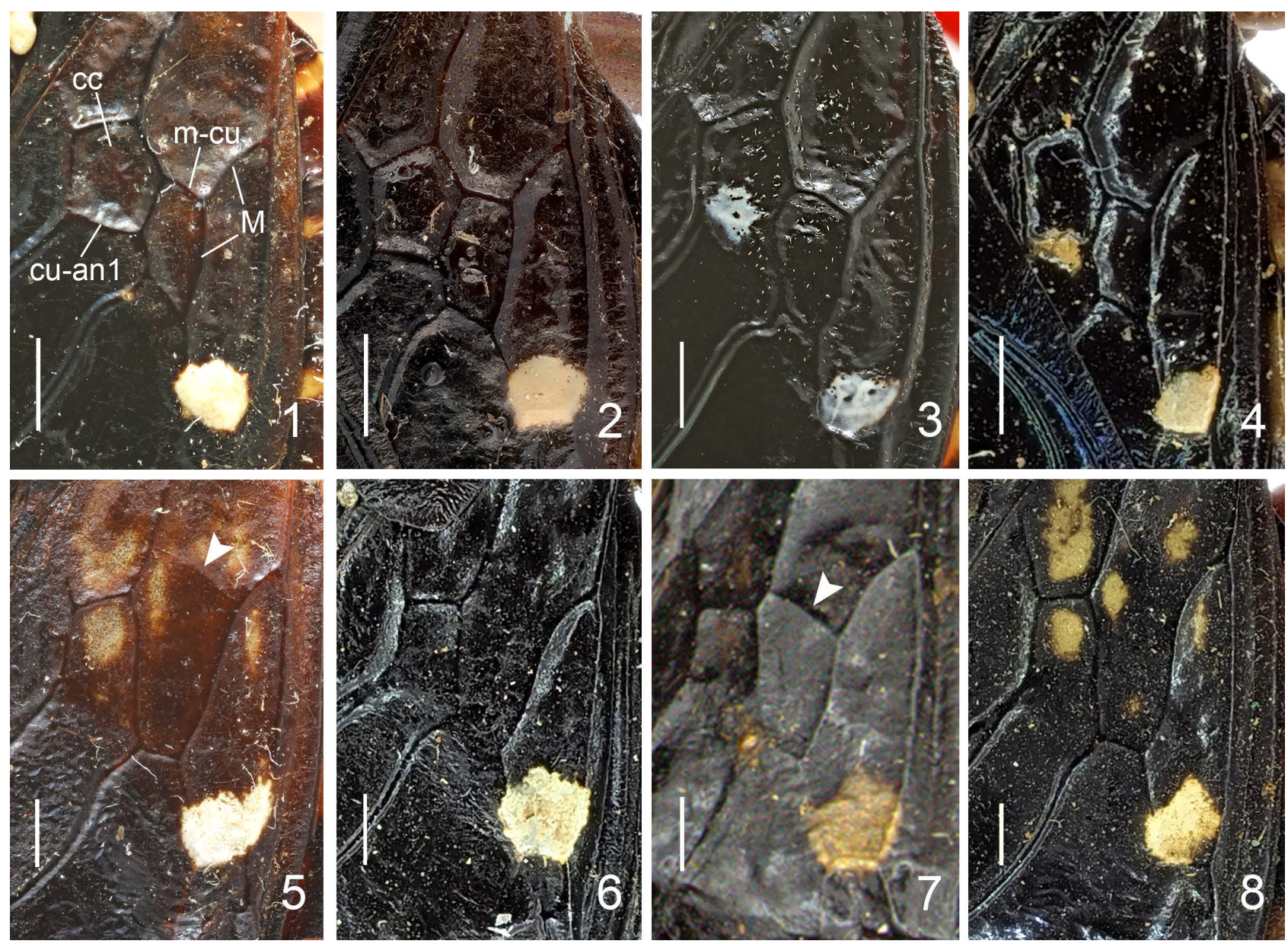

Figs 1-8. Corium of right hemelytron of some species of Ectinoderini in dorsal view. 1 - Amulius armillatus Breddin, 1900, non-type male; 2 - A. bipustulatus Bergroth, 1913, syntype, female; 3 - A. malayus Stål, 1867, non-type male; 4 - A. viscus Distant, 1911, syntype, female; 5 - Ectinoderus bipunctatus (Amyot \& Serville, 1843), non-type male, white arrow points to the remnant of the cross vein connecting $\mathrm{M}$ and Cu basad of the cubital cell; 6 - E. caedens Miller, 1958, paratype male; 7 - E. philippinensis Westwood, 1845, syntype female, white arrow points to the weakly developed cross vein connecting $\mathrm{M}$ and $\mathrm{Cu}$ basad of the cubital cell; $8-$ E. sumptuosus Distant, 1903 , syntype, male. Scale bars: 1.00 mm. Abbreviation: cc - cubital cell. @ MZH (Fig. 2), OUMHN (Fig. 7).

also differentiated by the shape of the anterolateral pronotal angles, which are more developed in Amulius than in Ectinoderus, and these two characters were historically used for distinguishing the two genera (Walker, 1873a; Stål, 1874; Distant, 1904). Despite some new species of Ectinoderini being subsequently described (e.g., Bergroth, 1913; Roepke, 1932; Miller, 1954, 1958), the ratio of the antennal scape to the pedicel as well as the development of the anterolateral pronotal angles are still useful characters for separating Amulius and Ectinoderus.

During the present study we examined eight species of Amulius and nine species of Ectinoderus (Table 1), and observed differences in hemelytral venation between the two genera. "Amulius sp." in Table 1 is very similar to A. quadripunctatus (the type species of Amulius) and may be that species, but we have not examined its type specimen(s). In species of Amulius, the section of $\mathrm{M}$ between the bifurcation of $\mathrm{R}+\mathrm{M}$ and the base of the apical external cell is connected to the cubital cell by a well-developed $\mathrm{m}-\mathrm{cu}$ cross vein, forming a small but distinct cell in the corium, thus the corium contains three cells; the cubital cell is relatively broad and pentagonal in shape (Figs 1-4). In con- trast, the $\mathrm{m}-\mathrm{cu}$ cross vein connecting $\mathrm{M}$ and the cubital cell is absent in members of Ectinoderus, and the cubital cell of this genus is quadrate in shape, with the apical border of the cell (cu-an1 cross vein) almost absent (Figs 5-8). In E. philippinensis Westwood, 1845, however, the section of $\mathrm{Cu}$ basal to the cubital cell is connected to $\mathrm{M}$ beyond the bifurcation of $\mathrm{R}+\mathrm{M}$ by a weakly developed, oblique cross vein (Fig. 7), but this is completely different from that observed in Amulius. A similar but more "degraded" condition is present in E. bipunctatus (Amyot \& Serville, 1843), which has a remnant of the cross vein connecting $\mathrm{M}$ and $\mathrm{Cu}$ basal to the cubital cell (Fig. 5). Based on the above-mentioned differences in the hemelytral venation, we concluded that the presence or absence of the m-cu cross vein connecting $\mathrm{M}$ and the cubital cell and the shape of the cubital cell can be used to distinguish Amulius and Ectinoderus, therefore herein these features are added to the revised generic diagnoses. However, examination of further species of the two genera is necessary for testing the applicability of these characters.

The genera of the tribe Ectinoderini can be distinguished using the following key. 


\section{Key to the genera of Ectinoderini}

1 Antennal scape shorter than head and pedicel; anterolateral angles of pronotum produced into long, spine-like processes; corium with $\mathrm{m}$-cu cross vein connecting $\mathrm{M}$ and cubital cell present; cubital cell pentagonal .......................... Amulius Stål

- Antennal scape longer than head and pedicel; anterolateral angles of pronotum short, weakly produced; corium with m-cu cross vein absent; cubital cell incomplete, quadrate .....

Ectinoderus Westwood

The identity of Parapanthous. Distant (1919a) established the genus Parapanthous to accommodate the new species $P$. spinicollis from "Indochina". He regarded this genus as "most nearly allied to the genus Panthous" and placed it in the subfamily Harpactorinae, whereas the genera Amulius and Ectinoderus were assigned to Apiomerinae by the same author (Distant, 1904, 1919b). This genus and species have not been recorded since and there are no subsequent works presenting original data about them. Miller $(1956,1971)$ treated Parapanthous as a member of Ectinoderinae and specifically pointed out that it might be a synonym of Amulius. Davis (1969) and Hsiao \& Ren (1981) also included this genus in their Ectinoderini and Ectinoderinae, respectively. Maldonado-Capriles (1990), nevertheless, placed Parapanthous in Harpactorinae and kept Amulius and Ectinoderus in Ectinoderinae and these placements were followed in several subsequent works (e.g., Schuh \& Slater, 1995; Ambrose, 2006; Schuh \& Weirauch, 2020).

An examination of the type material of $P$. spinicollis supports the placement of Parapanthous in Ectinoderini, as it shares the main diagnostic characters presented by Davis (1969) for defining the tribe, including the widely separated ocelli, short and straight labium, posteriorly expanded pronotum with partially exposed scutellum, nonstriated prosternal groove, and non-segmented fore tarsus. Likewise, the synonymy of Parapanthous with Amulius suggested by Miller $(1956,1971)$ is confirmed. The short antennal scape with a much longer pedicel, the strongly produced anterolateral pronotal angles, the presence of the above-mentioned m-cu cross vein in the corium, and the pentagonal cubital cell fulfil the diagnosis of Amulius, and there seems to be no reliable morphological characters to support the generic differentiation of $P$. spinicollis and the species currently placed in Amulius. Therefore, the following new subjective synonymy is proposed: Amulius Stål, $1865=$ Parapanthous Distant, 1919, syn. n.

\section{Amulius spinicollis (Distant, 1919), comb. $\mathrm{n}$.}

(Figs 9-21)

Parapanthous spinicollis Distant, 1919a: 207, 211. Syntypes $\left(2{ }^{\uparrow}\right)$ : Vietnam, Son La, Muong Va, BMNH.

Parapanthous spinicollis: Maldonado-Capriles, 1990: 252 (catalogue, distribution); Ambrose, 2006: 2399 (listed, distribution).

Diagnosis. Recognized within the genus by the following characters: body length 19.7-20.5 mm, generally blackish-brown; pronotum uniformly dark-brown; processes of anterolateral pronotal angles long, reaching posterior margin of ocelli, curved inwardly; fore femur dark- brown with a vague, light-brown annulus subapically; mid and hind femora blackish-brown, each with a vague, light coloured annulus subapically.

Redescription. Macropterous male (Figs 9-14). Coloration. Body generally blackish-brown. Head as general body colour, with ventral surface and neck slightly lighter (Figs 15-17). Antenna with preflagelloid yellowish-brown (Fig. 18). Labium as general body colour (Fig. 16). Pronotum dark-brown, with apical third of processes of anterolateral angles blackish (Fig. 15); propleuron and sternum dark-brown. Scutellum as general body colour, with apical half of median ridge whitish-yellow (Fig. 15); meso- and metapleura and sterna dark-brown, with midpart of mesosternum lighter (Fig. 17). Legs as general body colour; coxae and trochanters brown; fore femur dark-brown, with a vague, light-brown annulus subapically; fore tibia lightbrown, with a vague, dark-brown annulus subbasally, apical fourth blackish (Fig. 19); mid and hind femora each with a vague, light coloured annulus subapically. Hemelytron as general body colour, with a small, narrow, whitish wax spot on cu-an1 in cubital cell, and a larger, round, whitish wax spot before r-m near apex of corium (Fig. 20). Abdomen as general body colour; basal fourth of dorsal and ventral laterotergites of abdominal segments II to VII yellowish-brown (Figs 20, 21); in lectotype (present designation) the majority of sternites VI and VII yellowishbrown (Fig. 21).

Vestiture. Body sparsely covered with tiny, decumbent curly setae on head (including antennal scape), thorax, legs, corium of hemelytron and abdomen. Head with dense, short, decumbent to suberect curly setae on dorsal and lateral surfaces, and dense, short, erect curly setae on ventral surface; antennal pedicel and flagellomeres densely covered with tiny, decumbent to suberect setae; labium with tiny to short, suberect to erect setae; disc of pronotum largely glabrous, anterior and lateral margins as well as anterolateral processes densely covered with short, decumbent to suberect curly setae; meso- and metasterna largely glabrous; ventral surfaces of coxae and trochanters with dense, short, decumbent curly setae; fore femur with a row of tiny to short, erect curly setae on ventral surface, and several long, erect pubescence on apical third of dorsal surface; fore tibia densely covered with long, erect pubescence, length of pubescence longer than diameter of segment; fore tarsus densely covered with short to long, decumbent to erect, straight and curly setae; mid and hind tibiae with short, decumbent curly setae gradually becoming denser towards apex of segment; mid and hind tarsi densely covered with short to long, decumbent to suberect setae.

Structure. Body broad oval, somewhat dorsoventrally flattened. Head (Figs 15, 16) elongate, widest subapically, gradually narrowed posteriorly, 1.5 times as long as width across eyes, with dorsum finely inflated and venter flattened; anteocular part 0.46 times as long as postocular part. Eyes (Figs 15, 16) large, finely protruding anterolaterally. Ocelli (Figs 15, 16) small, widely separated; interocellar space 1.4 times as broad as interocular space. Antennifer- 

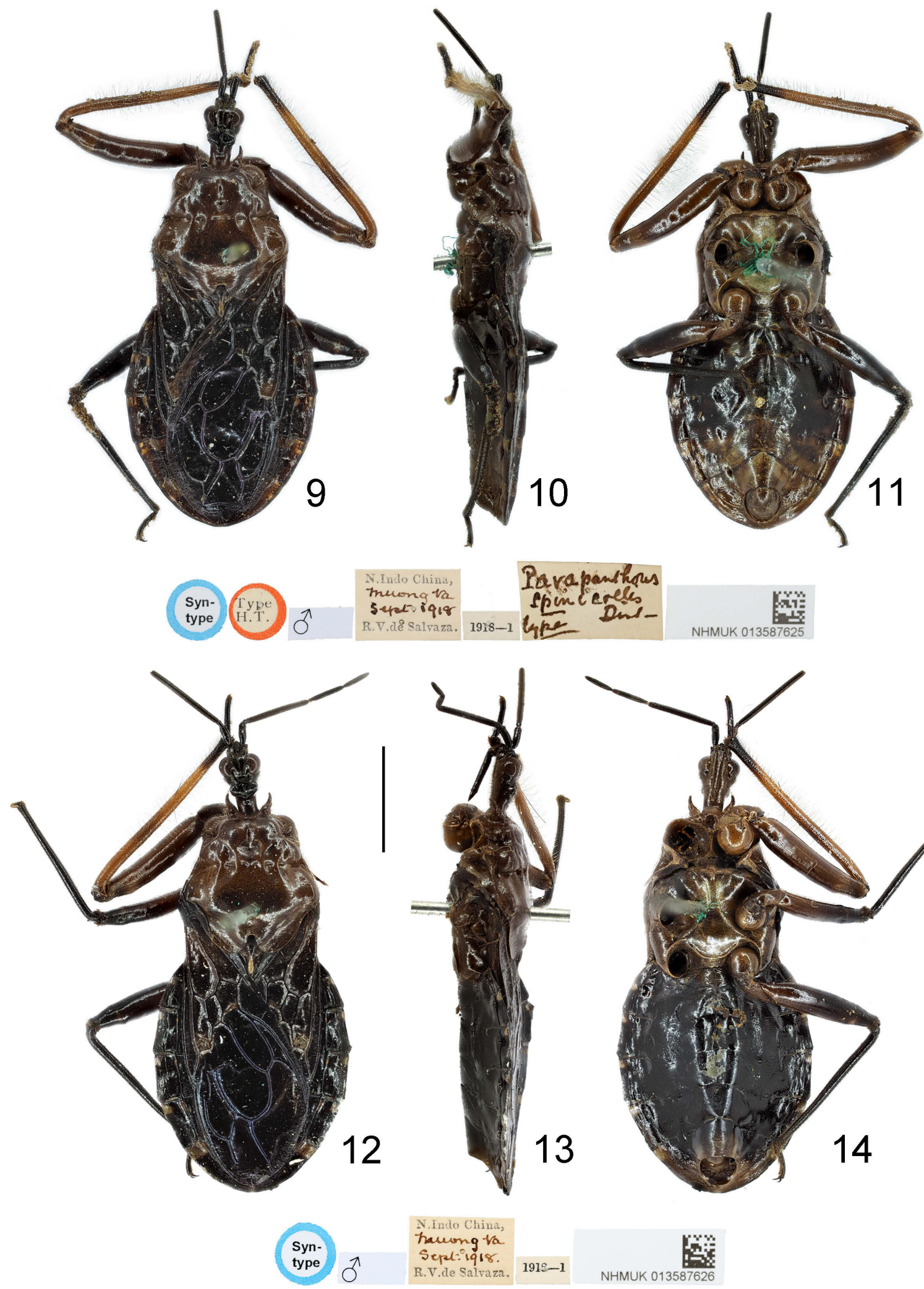

Figs 9-14. Parapanthous spinicollis Distant, 1919 [Amulius spinicollis (Distant, 1919), comb. n.], male, habitus with labels. 9-11 - lectotype; 12-14 - paralectotype. 9, 12 - dorsal view; 10, 13 - lateral view; 11, 14 - ventral view. Scale bar: $5.00 \mathrm{~mm}$.

ous tubercles distinct. Antennal scape stout; pedicel longest, 2.9 times longer than scape, 1.3 times as long as head; flagellomeres shorter than pedicel, basiflagellomere 1.1 times longer than distiflagellomere; prepedicellite, preflagelloid and intraflagelloid distinct (Fig. 18). Anteclypeus slightly elevated. Labium (Figs 16, 17) not surpassing anterior margin of prosternum; labial segment II short, reaching anterior margin of eye; segment III longest, 1.8 times as long as segments II and IV combined; segment IV shortest, conical. 

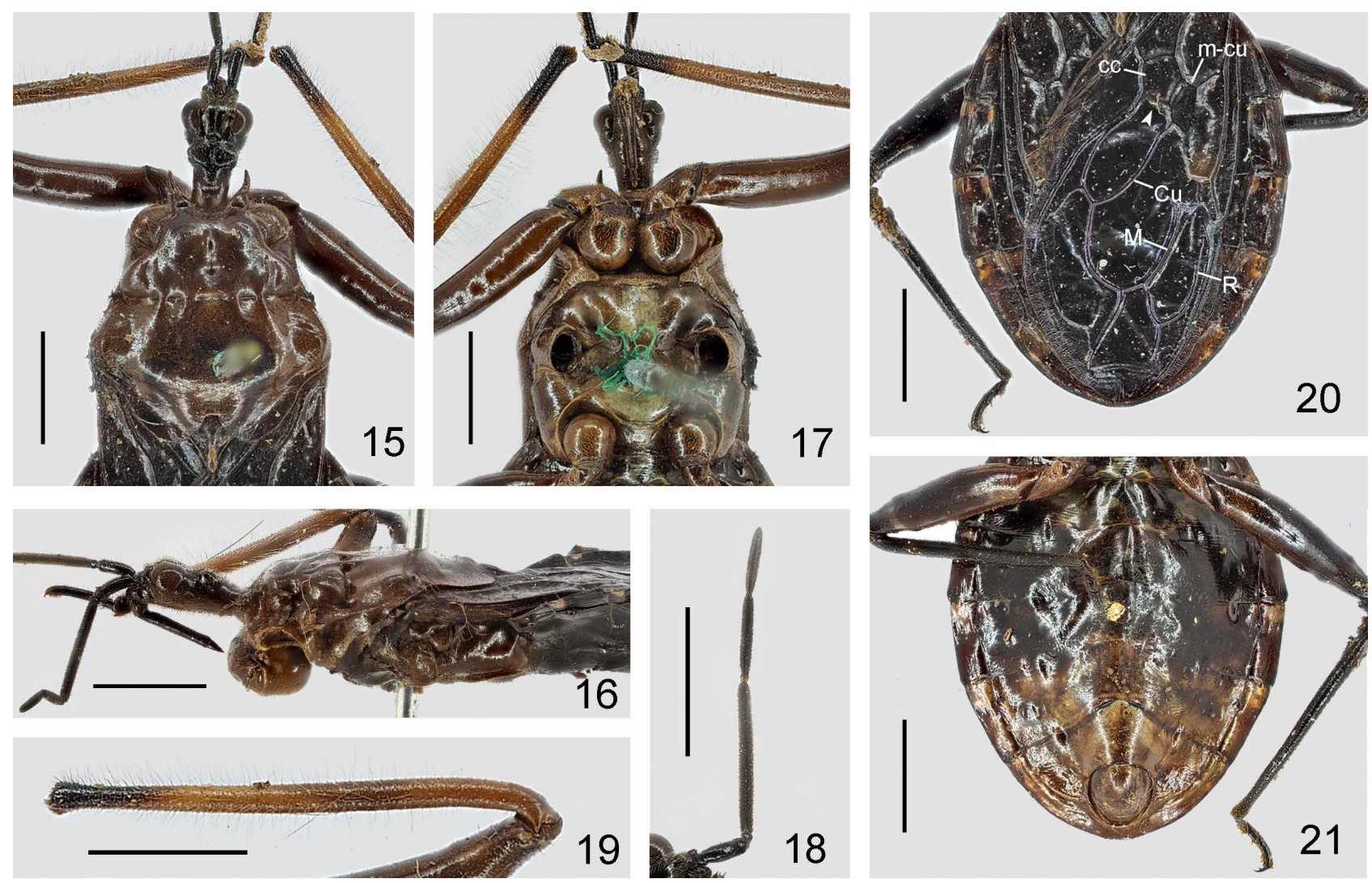

Figs 15-21. Parapanthous spinicollis Distant, 1919 [Amulius spinicollis (Distant, 1919), comb. n.], male. 15, 17, 19-21 - lectotype; 16 , 18 - paralectotype. 15-17 - anterior part of body; 18 - right antenna; 19 - right fore tibia; 20, 21 - posterior part of body, white arrow points to the small wax spot on cu-an1. 15, 18-20 - dorsal view; 16 - lateral view; 17, 21 - ventral view. Scale bar of 15-18, 20, $21=3.00 \mathrm{~mm}$; of $19=2.00 \mathrm{~mm}$. Abbreviation: $\mathrm{cc}-$ cubital cell.

Pronotum (Fig. 15) broad, length along midline 0.8 times as long as width across humeral angles, 1.85 times longer than head; anterior margin slightly concave; processes of anterolateral angles reaching posterior margins of ocelli, curved inwardly; anterior lobe 0.8 times as long as posterior lobe, with deep median longitudinal sulcus not reaching anterior pronotal margin and transverse sulcus; transverse sulcus distinct, interrupted by four short, submedian carinae; posterior lobe discally flat, posteriorly expanded into two broad, flat lobes; posterior margin deeply incised at middle. Episternal and epimeral lobes of propleuron strongly inflated, visible in dorsal view; prosternum small. Scutellum (Fig. 15) partially exposed, with a median longitudinal ridge, apex rounded.

Fore leg long and robust; fore coxa spherical, nearly contiguous in ventral view (Fig. 17); fore trochanter simple in shape; fore femur strongly thickened, slightly curved, somewhat flattened laterally; fore tibia (Fig. 19) slender, finely curved, 1.5 times as long as fore femur, slightly swollen at apex; fore tarsus 0.2 times as long as fore tibia, with a pair of tiny claws at apex. Mid and hind legs shorter and slenderer; mid and hind coxae widely separated; mid and hind femora moderately and strongly thickened, respectively; mid and hind tibiae 1.2 times as long as respective femur; mid and hind tarsi three-segmented, with a pair of small, simple claws at apices.

Hemelytron (Fig. 20) nearly reaching apex of abdomen in midline; corium with pentagonal cubital cell and two additional cells, outer one formed by $\mathrm{R}, \mathrm{M}$ and their cross vein, inner one formed by $\mathrm{M}, \mathrm{Cu}$ and their cross veins; membrane with apical external cell longer and broader than apical internal cell, and one additional cell formed by $\mathrm{R}, \mathrm{M}$ and their cross veins.

Abdomen (Figs 20,21) broad oval, 1.2 times as long as its maximum width; dorsal laterotergites largely exposed in dorsal view; ventral lateral tergites separated from respective sternite by a distinct connexival suture; anterior margin of sternite VII angularly curved anteriorly; abdominal spiracles situated on inner margin of basal third of ventral connexival sutures.

Female unknown.

Measurements [in mm, $\hat{\sigma}(\mathrm{n}=2)$ ]. Length of body (to apex of abdomen) 19.70-20.50; length of head 2.80-2.90; length of anteocular part 0.65 ; length of postocular part 1.40 ; width across eyes 1.85-1.95; interocular space 0.95 ; interocellar space 1.30 ; length of antennal segments I-IV $=1.00-1.05,3.50-3.75,1.55$, 1.40; length of labial segments II-IV $=0.6,1.85-2.00,0.45-0.50$; length of pronotum 5.20-5.40; length of anterior pronotal lobe 2.30 ; length of posterior pronotal lobe 2.90-3.10; width of anterior pronotal lobe 4.55-4.65; width of posterior pronotal lobe 6.20-6.35; median length of scutellum 1.45-1.75; length of fore femur, tibia, tarsus $=6.50,9.40-9.60,1.80$; length of mid femur, tibia, tarsus $=5.20,6.30$, ? (missing); length of hind femur, tibia, tarsus $=5.90,6.70-7.20,1.40-1.50$; length of hemelytron 12.50 13.00 ; length of abdomen 10.40-10.80; maximum width of abdomen 8.75-9.00. 
Type material examined. Lectotype (here designated) $(ð)$ : blue-margined syntype disc [pr.]; red-margined holotype disc [pr.]; “ $\widehat{\prime}$ ” [pr.]; "N. Indo China, [pr.] \Muong Va [hw.] \Sept. 1918 [hw.] \R.V. de Salvaza. [pr.]”; "1918-1" [pr.]; "Parapanthous \spinicollis $\backslash$ Dist $\backslash$ type" [hw.]; "NHMUK 013587625" [pr.]. Pinned, flagellomeres of left antenna, pedicel and flagellomeres of right antenna, tarsus of right fore leg, mid legs missing $(\mathrm{BMNH})$. Paralectotype $(\widehat{O})$ : blue-margined syntype disc [pr.]; " $\lambda "$ " [pr.]; "N. Indo China, [pr.] \Muong Va [hw.] $\backslash$ Sept. 1918 [hw.] \R.V. de Salvaza. [pr.]"; "1918-1" [pr.]; "NHMUK 013587626" [pr.]. Pinned, flagellomeres of left antenna, right fore, mid and hind legs, tarsus of left mid leg missing (BMNH).

Distribution. VIETNAM: Son La (Muong Va) $\left(20^{\circ} 53^{\prime} 26^{\prime \prime} \mathrm{N}, 103^{\circ} 37^{\prime} 1.4^{\prime \prime} \mathrm{E}\right)$ (Fig. 54).

Comparative notes. Amulius spinicollis comb. $\mathrm{n}$. is not conspecific with other species of Amulius. The uniformly dark-brown pronotum and the nearly unicoloured fore, mid and hind femora of this species are very distinct within the genus, whereas its congeners usually have brilliant yellow-orange to reddish colour patterns and sometimes are conspicuously bicolorous. Amulius spinicollis comb. n. is morphologically similar to A. malayus Stål, 1867 from the Indochinese Peninsula and Southern China, but it can be clearly distinguished from the latter by the completely different body colour and the shape of the anterolateral pronotal processes (long, reaching the posterior margin of the ocelli, curved inwardly in A. spinicollis comb. n. vs. short, far removed from the posterior margin of the ocelli, straight in A. malayus).

Remarks. This species was originally described based on specimens from "N. Indochina; Muong Va" (Distant, 1919a). The locality Muong Va currently belongs to Sop Cop, Son La, Vietnam. Ambrose's (2006) statement that this species occurs in "India and China" may be due to a misinterpretation of "Indochina". This species has, as yet, neither been reported from China nor from India.

\section{Genus Ectinoderus Westwood, 1843}

Ectinoderus Westwood, 1843: 466. Type species: Ectinoderus longimanus Westwood, 1843 (by monotypy). As subgenus of an unknown genus (see remarks below).

Pristhevarma Amyot \& Serville, 1843: 355. Type species: Pristhevarma bipunctata Amyot \& Serville, 1843 (by monotypy). Synonymized by Westwood (1845: 120).

Ectinoderus: Westwood, 1845: 120 (redescription, upgraded to generic level); Herrich-Schäffer, 1850: 92 (in key); HerrichSchäffer, 1853: 85 (catalogue); Stål, 1865: 99 (in key); Stål, 1867: 245 (catalogue); Stål, 1871: 691 (listed, fauna of Philippines); Walker, 1873a: 69 (in key); Walker, 1873b: 75 (catalogue); Stål, 1874: 44, 45 (in key, catalogue); Lethierry \& Severin, 1896: 149 (catalogue); Distant, 1904: 326 (in key, redescription, distribution, fauna of India, Sri Lanka and Myanmar); Roepke, 1932: 5 (list of species); Miller, 1938: 750 (listed, biology); Miller, 1942: 55 (listed, biology); Miller, 1956: 113, 114 (listed, biology); Davis, 1969: 87 (listed); Miller, 1971: 136 (listed, biology); Hsiao \& Ren, 1981: 412 (listed); Maldonado-Capriles, 1990: 24 (catalogue); Kerzhner, 1992: 48 (nomenclature); Schuh \& Slater, 1995: 157 (listed); Schuh \& Weirauch, 2020: 354 (listed).

Revised diagnosis. Ectinoderus can be distinguished from Amulius by a combination of the following charac- ters: antennal scape longest, distinctly longer than head and pedicel; anterolateral angles of pronotum produced into a pair of very short processes; hemelytron with m-cu cross vein connecting $\mathrm{M}$ and cubital cell absent, cubital cell quadrate.

Diversity and distribution. The genus now contains eleven species distributed in India, the Indochinese Peninsula and Malay Archipelago.

Remarks. Ectinoderus was originally described by Westwood (1843) as a "Subg. nov.", without mention of its genus. Westwood (1845) then redescribed Ectinoderus as a genus and stated in the first paragraph: "the third species [referring to its type species, E. longimanus] differs in its structural characters so materially from the other groups in the family, that I have not hesitated in adding another to the already numerous genera of Reduviidae". Westwood (1845) compared Ectinoderus with three other genera (Arilus Hahn, 1831, Notocyrtus Burmeister, 1835 and Diaspidius Westwood, 1837), which have a posteriorly dilated pronotum, but still did not mention its original genus. Subsequent works, such as Herrich-Schäffer (1853), Stål (1867, 1874), Walker (1873b), Lethierry \& Severin (1896), Distant (1904) and Maldonado-Capriles (1990), all simply treated it as a genus without any comment on its original subgeneric placement.

The original description of Ectinoderus (Westwood, 1843) was recorded based on Westwood's oral narration on $1^{\text {st }}$ Aug. 1842, and its later published redescription (Westwood, 1845) could be considered its more formal taxonomic arrangement. However, since the oral records were formally published on $1^{\text {st }}$ Jun. 1843 the description is considered valid from that date (Wheeler, 1912; Kerzhner, 1992). This indicates that Ectinoderus has never been formally treated as a subgenus of a particular genus, therefore the name longimanus is originally combined with Ectinoderus rather than with any other genus.

Ectinoderus confragosus (Distant, 1919), comb. $\mathrm{n}$. (Figs 22-53)

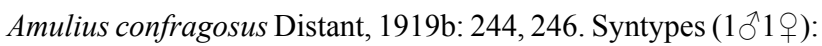
Laos, Luang Prabang, BMNH.

Amulius confragosus: Maldonado-Capriles, 1990: 24 (catalogue, distribution).

Diagnosis. Recognized within the genus by the following characters: body length $22.0-29.7 \mathrm{~mm}$, generally brown to dark-brown; pronotum nearly uniformly brown; anterior pronotal lobe nearly half as long as posterior lobe; fore femur light-brown basally, gradually darkened towards apex, dark-brown subapically, apical third yellowishbrown; mid and hind femora dark-brown basally, gradually darkened towards apices, apices blackish-brown, each with two subapical, light-yellowish-brown spots forming an incomplete annulus; laterotergites of abdominal segments II to V bicolorous, of VI and VII uniformly yellowish-brown.

Redescription. Macropterous male and female (Figs 22-33). Coloration. Body generally brown to darkbrown. Head blackish-brown, with a small, whitish-yellow spot under ocellus on each side (Figs 34, 35). Antenna 

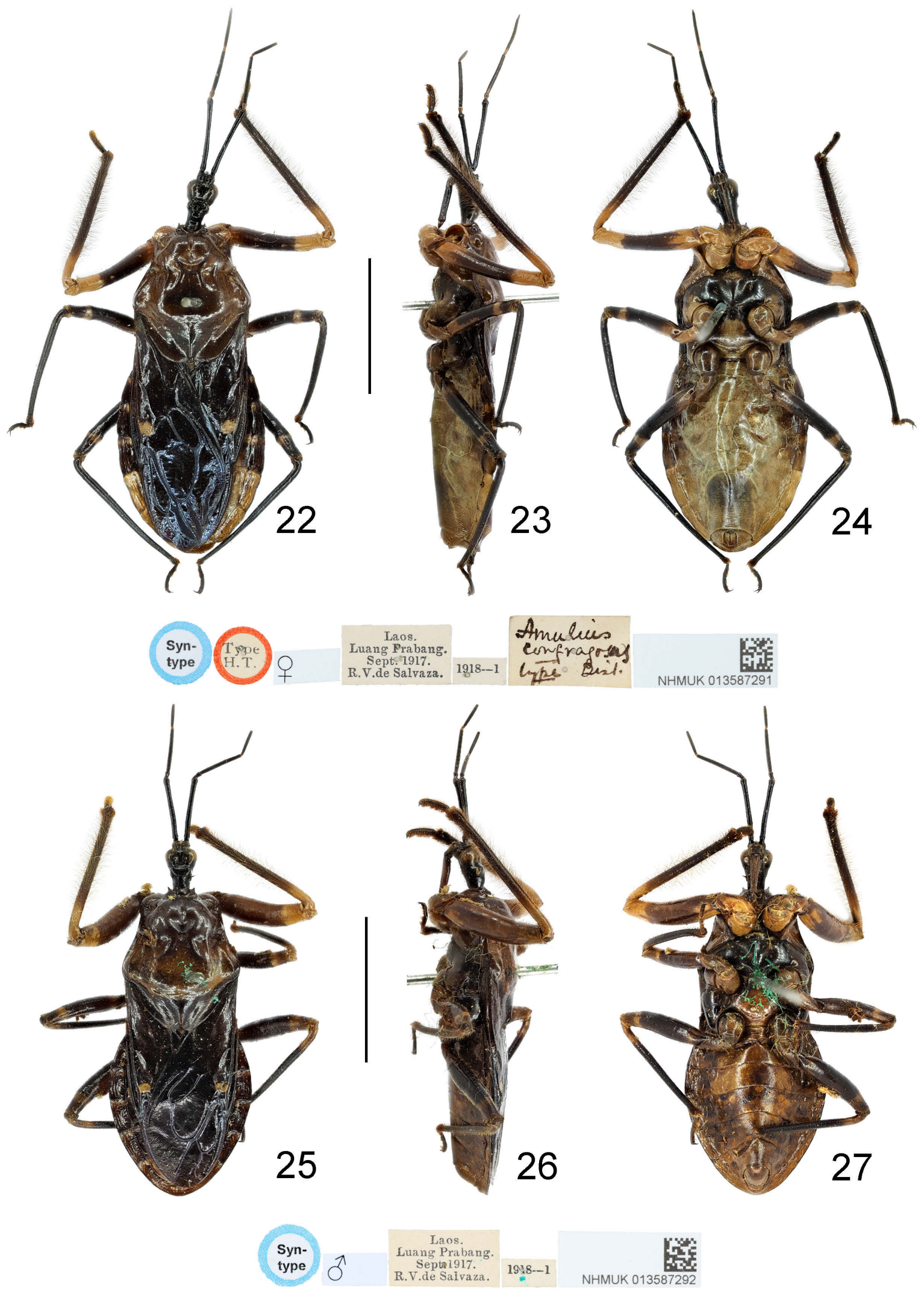

Figs 22-27. Amulius confragosus Distant, 1919 [Ectinoderus confragosus (Distant, 1919), comb. n.], habitus with labels. 22-24 - female lectotype; 25-27 - male paralectotype. 22, 25 - dorsal view; 23, 26 - lateral view; 24, 27 - ventral view. Scale bars: $10.00 \mathrm{~mm}$.

blackish-brown; prepedicellite, base and apex of pedicel, preflagelloid, base of basiflagellomere, intraflagelloid yellowish-brown. Labium blackish-brown, with labial segment III slightly lighter (Fig. 35). Pronotum brown, with anterior margin and anterolateral angles slightly darker (Fig. 34); propleuron and sternum light-brown. Exposed part of scutellum yellowish-brown; meso- and metapleuron as general body colour, mesosternum blackish-brown, 

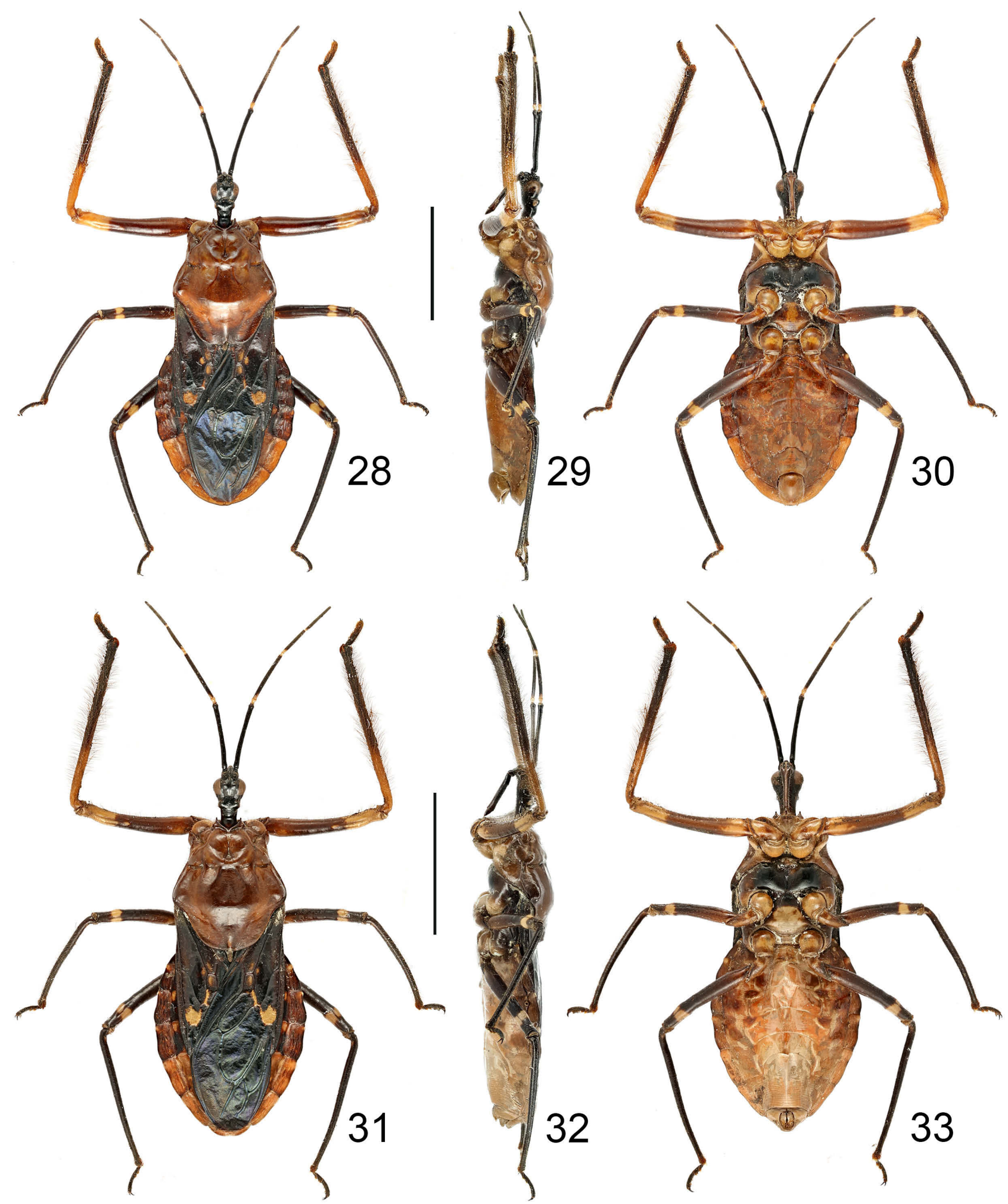

Figs 28-33. Ectinoderus confragosus (Distant, 1919), comb. n., habitus. 28-30 - non-type male; 31-33 - non-type female. 28, 31 - dorsal view; 29,32 - lateral view; 30, 33 - ventral view. Scale bars: $10.00 \mathrm{~mm}$.

metasternum light-brown (Fig. 36). Fore coxa light-brown; fore trochanter, mid and hind coxae and trochanters brown to dark-brown; fore femur light-brown basally, gradually darkened towards apex, dark-brown subapically, with a small, yellowish-brown spot subapically, apical third yellowish-brown (Fig. 37); fore tibia light-yellowish-brown on basal third, brown subbasally, gradually darkened to- wards apex, apex blackish-brown (Fig. 37); mid and hind femora dark-brown basally, gradually darkened towards apices, apices blackish-brown, each with two subapical, light-yellowish-brown spots forming an incomplete annulus; mid and hind tibiae blackish-brown, base of ventral surface with a small, yellowish-brown spot; tarsi blackishbrown. Hemelytron blackish-brown, with whitish-yellow 

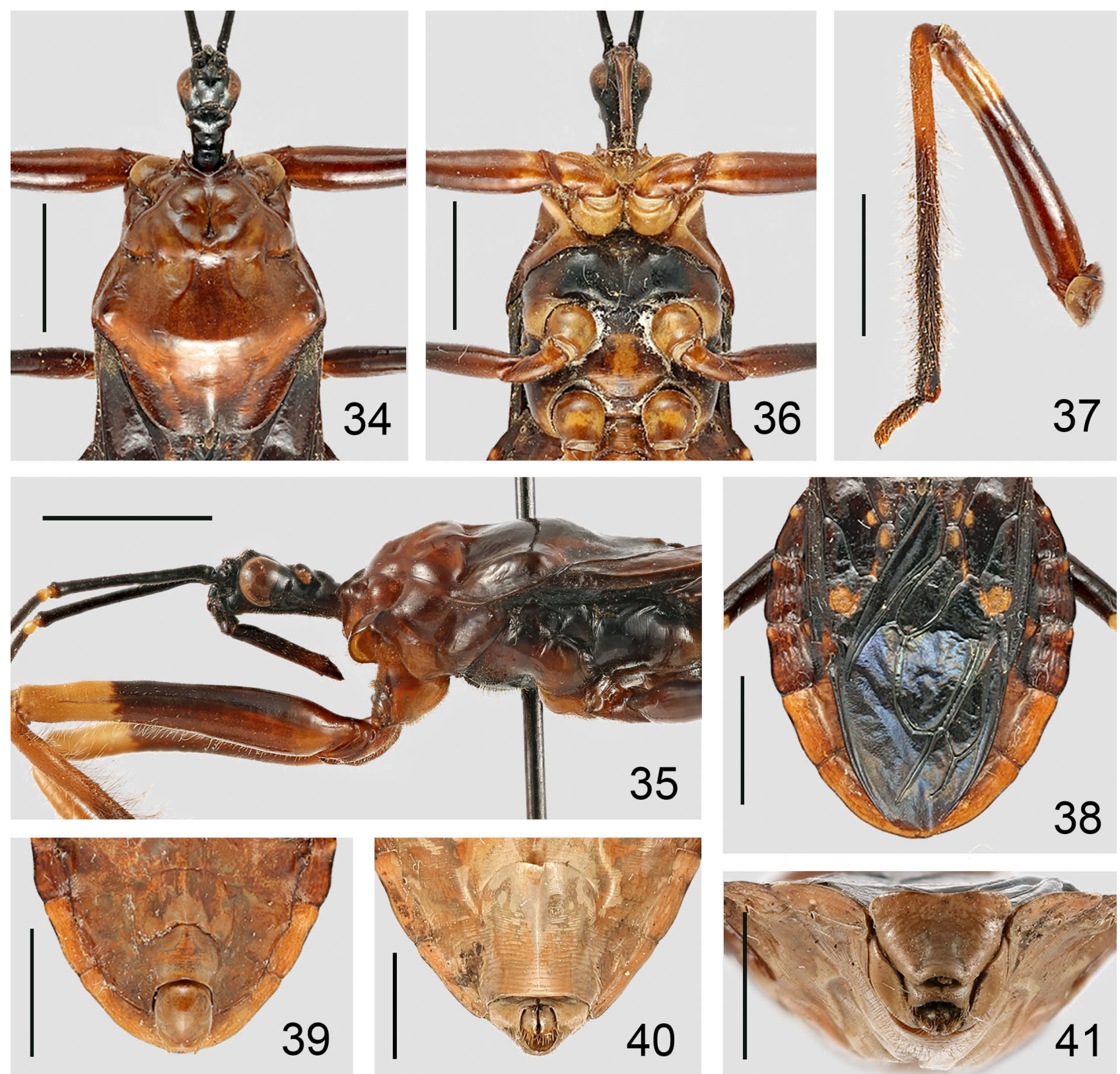

Figs 34-41. Ectinoderus confragosus (Distant, 1919), comb. n.. 34-39 - non-type male; 40, 41 - non-type, female. 34-36 - anterior part of body; 37 - right fore leg; 38 - posterior part of body; 39-41 - apex of abdomen. 34, 37, 38 - dorsal view; 35 - lateral view; 36, 39, 40 - ventral view; 41 - caudal view. Scale bar of $34-39=5.00 \mathrm{~mm}$; of $40,41=3.00 \mathrm{~mm}$.

wax at base (Fig. 38); corium with a large, round, whitish wax spot before $\mathrm{r}-\mathrm{m}$ near apex, section of $\mathrm{Cu}$ at base of apical internal cell whitish-yellow (Fig. 38), in some specimens with five additional whitish wax spots located in cubital cell, each side of $\mathrm{Cu}$ before cubital cell, front and back of bifurcation of $\mathrm{R}+\mathrm{M}$, respectively. Abdomen yellowishbrown; laterotergites of abdominal segments II to $\mathrm{V}$ darkbrown with basal fourth yellowish-brown (Fig. 38).

Vestiture. Body sparsely covered with tiny and short, erect curly setae on head (including labium), thorax, legs, corium of hemelytron and abdomen; antennal scape with sparse, tiny, suberect to erect setae, pedicel with dense, tiny, suberect setae, flagellomeres with dense, tiny, suberect setae and tiny, decumbent pubescence; pronotum, meso- and metapleural and sterna largely glabrous; ven- tral surfaces of coxae and trochanters with dense, short, erect setae; femora with sparse, tiny, erect setae, fore femur with relatively long, erect setae on venter and apical third of dorsum, gradually becoming denser towards apex of segment; fore tibia densely covered with long, erect pubescence, length of pubescence longer than diameter of segment; fore tarsus densely covered with short to long, decumbent to erect, straight and curly setae; mid and hind tibiae with short, decumbent curly setae gradually becoming denser towards apex of segment; mid and hind tarsi densely covered with short to long, decumbent to suberect setae.

Structure. Body elongate oval, somewhat dorsoventrally flattened. Head (Figs 34-36) elongate, widest subapically, gradually narrowed posteriorly, $1.7(\overbrace{}^{\Uparrow}) / 1.8$ (ㅇ) 

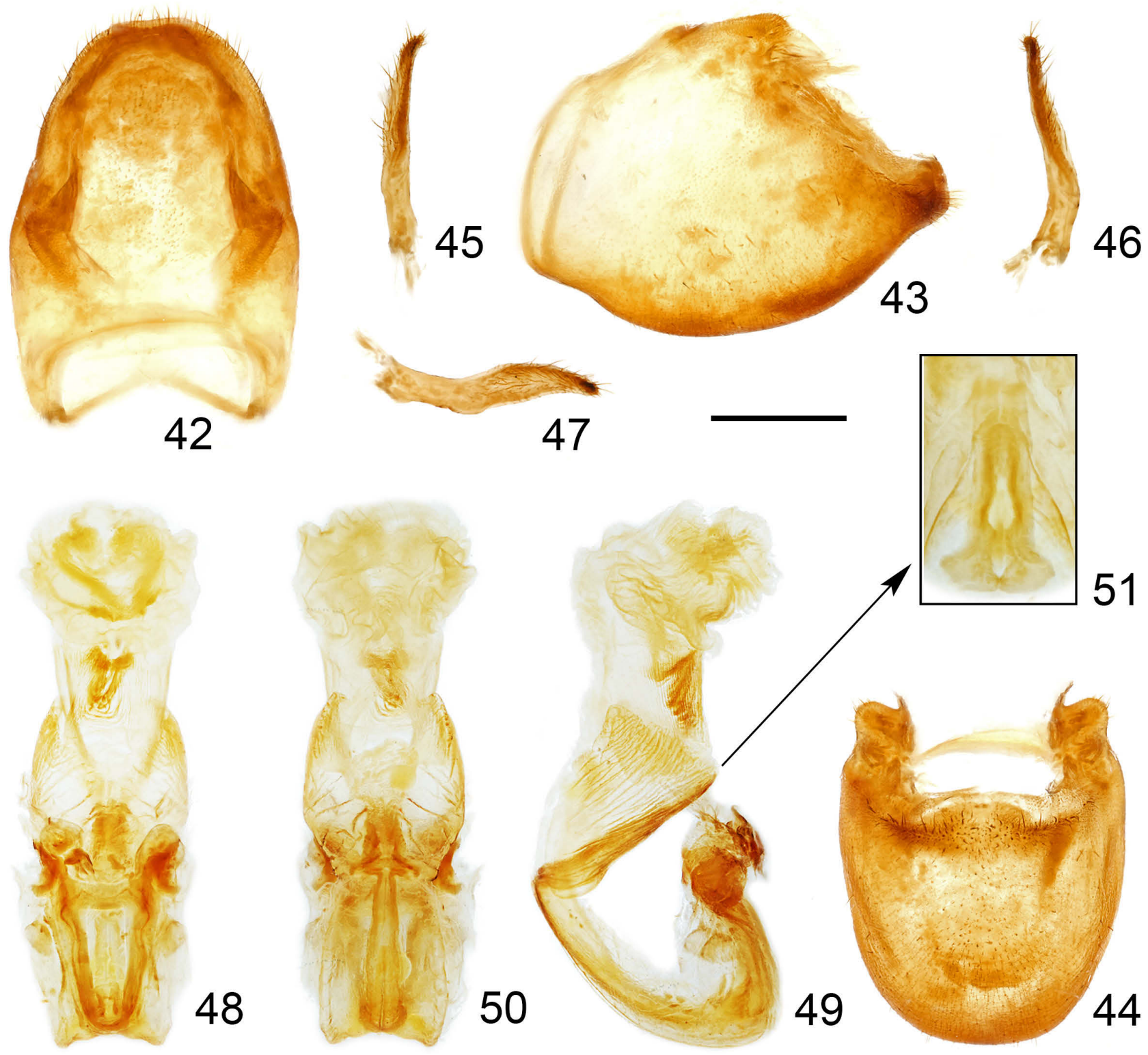

Figs 42-51. Ectinoderus confragosus (Distant, 1919), comb. n., non-type male. 42-44 - pygophore; $45-47$ - paramere; 48-50 - phallus; 51 - struts. $42,48,51$ - dorsal view; 43,49 - lateral view; 44 - caudal view; 50 - ventral view. Scale bar of $42-50=1.00 \mathrm{~mm}$; of $51=$ $1.33 \mathrm{~mm}$.

times as long as width across eyes, with dorsum finely inflated and venter flattened; anteocular part $0.45\left(\zeta^{\Uparrow}\right) / 0.4$ $(+)$ times as long as postocular part. Eyes (Figs 34, 35) large, finely protruding anterolaterally. Ocelli (Figs 34, 35) small, widely separated; interocellar space $1.3(\overbrace{}^{\Uparrow}) / 1.45$ $(9)$ times as broad as interocular space. Antenniferous tubercles distinct. Antennal scape longest, $1.4\left(\zeta^{\lambda}\right) / 1.3$ (ㅇ) times longer than pedicel, $1.25\left(\delta^{\Uparrow}\right) / 1.2$ (ㅇ) times longer than head; pedicel 0.9 times as long as head; flagellomeres shorter than pedicel, basiflagellomere slightly shorter than distiflagellomere; prepedicellite, preflagelloid and intraflagelloid distinct. Anteclypeus slightly elevated. Labium (Figs 35, 36) slightly surpassing anterior margin of prosternum; labial segment II short, reaching anterior margin of eye; segment III longest, $2.1(\succsim) / 2.2$ (ठ) times as long as segments II and IV combined; segment IV shortest, conical.
Pronotum (Fig. 34) broad, slightly inflated dorsally, length along midline $1.1(\widehat{ठ}) / 1.05$ () times as long as width across humeral angles, $2.3(\delta) / 2.0$ ( $(+)$ times longer than head; anterior margin slightly concave; processes of anterolateral angles reaching basal third of posterior lobe of head in dorsal view; anterior lobe nearly half as long as posterior lobe, with deep median longitudinal sulcus not reaching anterior pronotal margin and transverse sulcus; transverse sulcus distinct, interrupted by four short, submedian carinae; posterior lobe discally flat, posteriorly declined, expanded into two broad, flat lobes, with a short, distinct, median longitudinal ridge; posterior margin shortly incised at middle. Episternal and epimeral lobes of propleuron strongly inflated, visible in dorsal view; prosternum small. Scutellum (Figs 34, 38) largely hidden by pronotum, with extreme apex exposed. 

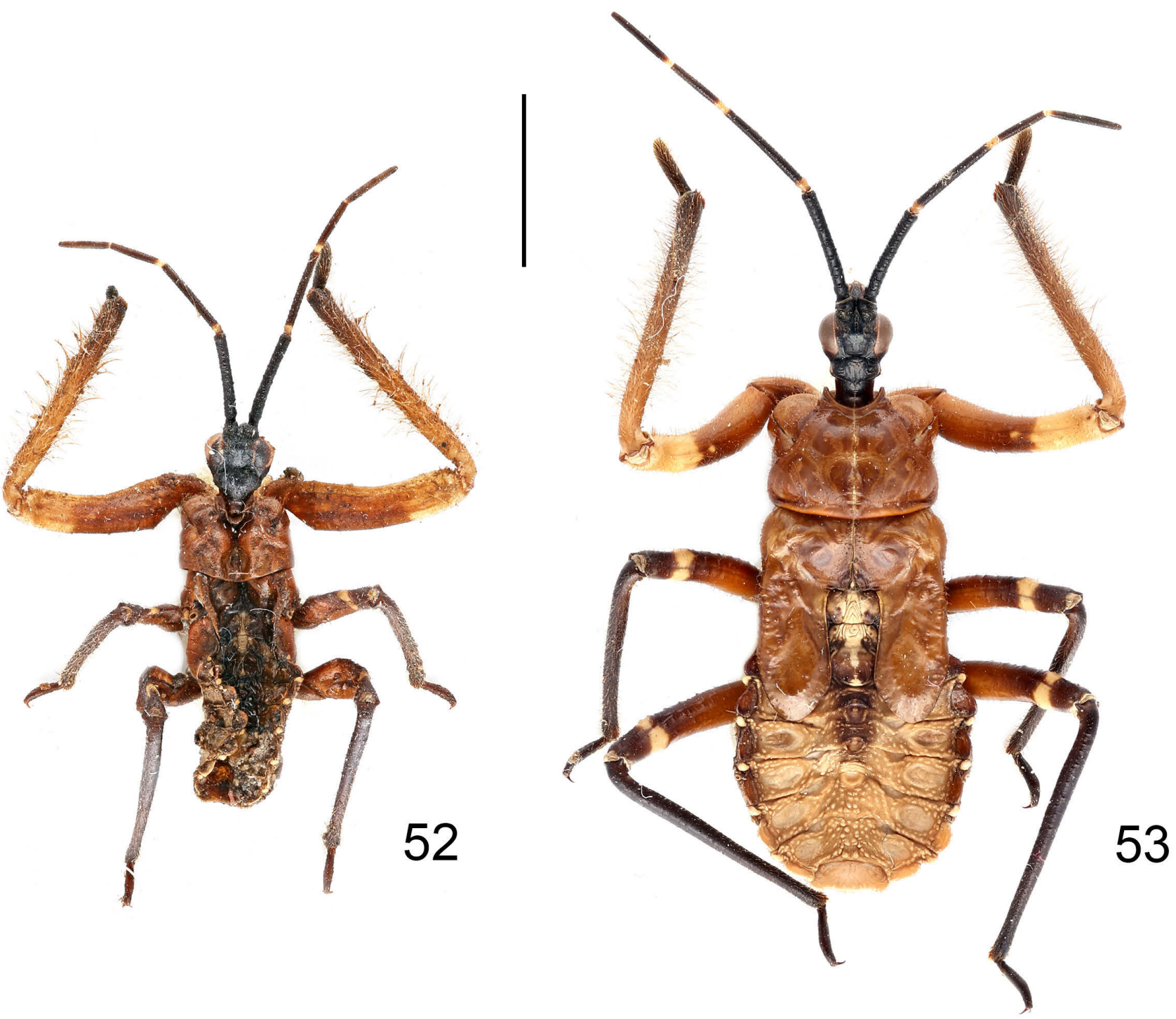

Figs 52, 53. Ectinoderus confragosus (Distant, 1919), comb. n., nymphs, dorsal view. 52 - third-instar; 53 -fifth-instar. Scale bar: 5.00 $\mathrm{mm}$.

Fore leg long and robust; fore coxa spherical, nearly contiguous in ventral view (Fig. 36); fore trochanter simple in shape; fore femur (Fig. 37) strongly thickened, slightly curved, somewhat flattened laterally, basally forming a small tubercle with apex of fore trochanter on ventral surface; fore tibia (Fig. 37) slender, finely curved, 1.3 times as long as fore femur, slightly swollen at apex; fore tarsus 0.2 times as long as fore tibia, with a pair of tiny claws at apex. Mid and hind legs shorter and slenderer; mid and hind coxae widely separated; mid and hind femora moderately and strongly thickened, respectively; mid and hind tibiae

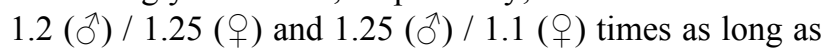
respective femur; mid and hind tarsi three-segmented, with a pair of small, simple claws at apices.

Hemelytron (Fig. 38) nearly reaching or slightly surpassing apex of abdomen in midline; corium with quadrate cubital cell and one additional cell formed by $\mathrm{R}, \mathrm{M}$ and their cross vein; membrane with apical external cell longer and broader than apical internal cell, and one additional cell formed by R, M and their cross veins.

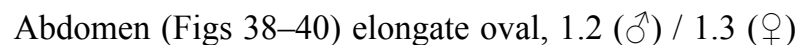
times as long as its maximum width; dorsal laterotergites largely exposed in dorsal view; ventral lateral tergites separated from respective sternite by distinct connexival su-

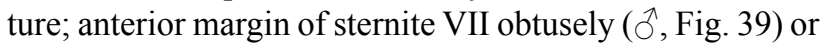
broadly (q, Fig. 40) curved anteriorly; abdominal spiracles situated at inner margin of basal third of ventral connexival sutures.

Male genitalia: Pygophore (Figs 42-44) oblong, ventral surface arched; anterior dorsal sclerotization narrow; posterior margin broadly rounded, without median process; paramere insertion with a protuberance. Paramere (Figs 45-47) long and slender, evenly bent, narrowed towards apex, apically blunt. Phallus (Figs 48-50) robust; articulatory apparatus thick, angularly curved; basal plates long and thick, widely separated; ponticulus basilaris slender, slightly curved; dorsal connectives short; basal foramen large and elongated; basal plate extension wide, nearly 1.5 times longer than basal plates; phallosoma weakly sclerotized; dorsal sclerotized plate short and broad; struts 


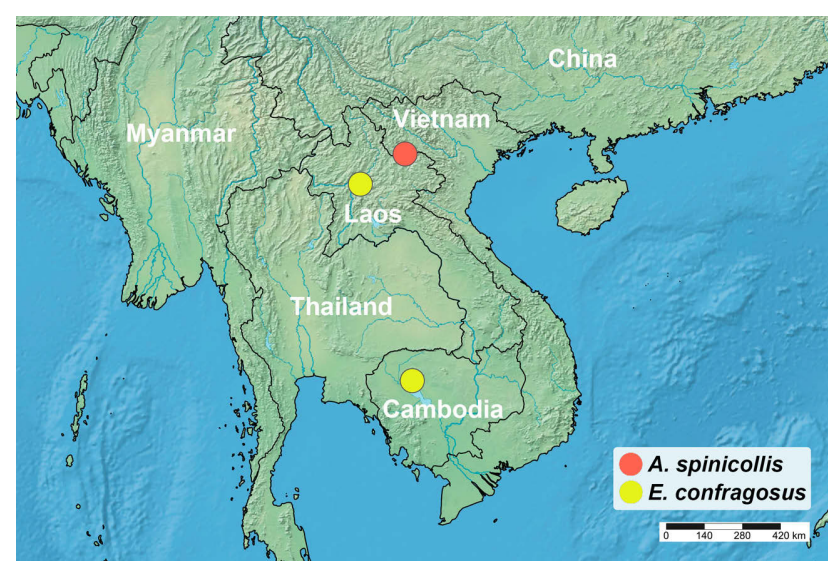

Fig. 54. Known distribution of two species of Ectinoderini.

largely fused, short, reaching midpart of dorsal sclerotized plate (Fig. 51); endosoma tubular, apical part without distinct sclerotized structures.

Female genitalia: Tergite VIII dorsal and horizontal, semicircular; tergite IX (Fig. 41) vertical, inverted trapezoid, anterior portion forming transverse edge as a part of connexivum, posterior margin slightly concave; valvifer I (Figs 40, 41) broad, inner margin concave, apical margin rounded; valvula I (Figs 40, 41) small, apical half covered with long setae, apex blunt; styloids fused to form a wide, arched sclerite (Figs 40, 41).

Measurements [in mm, $\hat{\sigma}(\mathrm{n}=7) / q(\mathrm{n}=8)]$. Length of body (to apex of abdomen) 22.00-29.70/25.10-27.60; length of head $3.40-4.40 / 4.10-4.20$; length of anteocular part 0.60-1.00 / $0.70-0.80$; length of postocular part 1.70-1.90 / 1.65-1.90; width across eyes 2.10-2.50/2.25-2.40; interocular space 1.00-1.50 / 1.10-1.20; interocellar space 1.40-1.90 / 1.65-1.70; length of antennal segments I-IV $=4.00-5.80 / 4.90-5.00,2.80-4.20$ / 3.50-3.90, 1.70-2.60 / 2.10-3.10, 2.20-2.80 / 2.40; length of labial segments II-IV $=0.80-0.90 / 0.70-1.00,2.50-3.30 / 2.90$ $3.00,0.50-0.60 / 0.50$; length of pronotum $8.50-9.80 / 8.00-8.50$; length of anterior pronotal lobe 2.50-3.80/2.70-3.10; length of posterior pronotal lobe $6.00 / 5.30-5.40$; width of anterior pronotal lobe 5.30-7.30 / 5.30-5.70; width of posterior pronotal lobe $7.10-9.30$ / 7.60-8.00; median length of scutellum $0.70-1.30 /$ 1.00 ; length of fore femur, tibia, tarsus $=8.10-10.80 / 8.90-9.60$, $10.50-14.50 / 11.50-12.50,2.00-2.30 / 2.00-2.20$; length of mid femur, tibia, tarsus $=6.30-8.20 / 6.00-7.50,7.40-10.50 / 8.00$ $9.00,1.70-2.10 / 1.70-2.00$; length of hind femur, tibia, tarsus $=7.20-9.50 / 7.30-7.80,8.20-10.60 / 9.50-10.80,2.00-2.40 /$ 1.90-2.10; length of hemelytron 13.60-18.50 / 16.70-17.20; length of abdomen 11.70-14.50 / 12.90-14.30; maximum width of abdomen 9.30-12.70/9.40-11.00.

Third instar nymph (Fig. 52). Coloration. Body generally brown, slightly tinged with reddish-brown, colour similar to adult; wing pad dark brown; midparts of metasternum and abdominal tergite I, abdominal spiracles light-yellowish-brown. Vestiture. Similar to adult; wing pad and abdomen with several small, wart-like tubercles each bearing a tiny, erect seta at apex. Structure. Similar to adult in body shape; body surface weakly sclerotized. Head 1.2 times as long as width across eyes; anteocular part 0.33 times as long as postocular part; width across eyes 2.2 times as broad as interocular space; antennal scape 1.15 times longer than head, 1.2 times longer than pedicel; labium distinctly surpassing anterior margin of prosternum. Pronotum 0.6 times as long as its maximum width. Fore leg long and robust, fore tibia 1.35 times longer than fore femur; mid and hind legs short and stout. Apex of wing pad reaching anterior margin of abdominal tergite II. Lateral margin of each abdominal segment rounded, making outline of abdomen undulated; dorsal abdominal glands present on posterior parts of tergites II, III and IV.

Measurements [in $\mathrm{mm}, \mathrm{n}=1$ ]. Length of body 11.30; length of head 2.40; length of anteocular part 0.40 ; length of postocular part 1.20; width across eyes 2.00 ; interocular space 0.90 ; length of antennal segments I-IV $=2.80,2.30,1.50,1.80$; length of labial segments II-IV $=0.50,1.50$, ? (hidden); length of pronotum 1.80; maximum width of pronotum 3.00 ; length of fore femur, tibia, tarsus $=5.90,8.00,1.60$; length of mid femur, tibia, tarsus $=4.20,5.60,1.20$; length of hind femur, tibia, tarsus $=4.70,6.40$, 1.40 ; length of wing pad 2.60; length of abdomen 5.00; maximum width of abdomen indeterminate as it is twisted.

Fifth instar nymph (Fig. 53). Coloration. Body generally light brown, colour similar to adult; midparts of metasternum and abdominal tergite I, abdominal spiracles lightyellowish-brown; midparts of abdominal tergites II and III dark-greyish. Vestiture. Similar to adult; wing pad and abdomen with many small, wart-like tubercles each bearing a tiny, erect seta at apex. Structure. Similar to adult in body shape; body surface relatively well sclerotized. Head 1.6 times as long as width across eyes; anteocular part 0.4 times as long as postocular part; width across eyes 2.1 times as broad as interocular space; antennal scape 1.1 times longer than head, 1.2 times longer than pedicel; labium distinctly surpassing anterior margin of prosternum. Pronotum 0.6 times as long as its maximum width. Fore leg long and robust, fore tibia 1.3 times longer than fore femur; mid and hind legs short and stout. Apex of wing pad reaching anterior margin of abdominal tergite III. Abdomen relatively weakly sclerotized; lateral margin of each abdominal segment rounded, making outline of abdomen undulated; dorsum and venter with regularly arranged sclerotized plates; dorsal abdominal glands present on posterior parts of tergites II, III and IV.

Measurements [in $\mathrm{mm}, \mathrm{n}=1$ ] . Length of body 17.70 ; length of head 3.40; length of anteocular part 0.60 ; length of postocular part 1.40; width across eyes 2.10 ; interocular space 1.00 ; length of antennal segments I-IV $=3.70,3.00,1.80,2.00$; length of labial segments II-IV $=0.60,2.50,0.50$; length of pronotum 3.20 ; maximum width of pronotum 5.00; length of fore femur, tibia, tarsus $=7.50,10.00,1.80$; length of mid femur, tibia, tarsus $=$ $5.00,7.00,1.60$; length of hind femur, tibia, tarsus $=6.40,8.30$, 1.80 ; length of wing pad 5.50; length of abdomen 7.80; maximum width of abdomen 7.00 .

Type material examined. Lectotype (here designated) (q): blue-margined syntype disc [pr.]; red-margined holotype disc [pr.]; “○” [pr.]; "Laos. \Luang Prabang. \Sept. 1917. \R.V. de Salvaza." [pr.]; "1918-1" [pr.]; "Amulius $\backslash$ confragosus $\backslash$ type Dist." [hw.]; "NHMUK 013587291" [pr.]. Pinned, distiflagellomere of both antennae missing (BMNH). Paralectotype (ð): blue-margined syntype disc [pr.]; " $О$ " [pr.]; "Laos. \ Luang Prabang. \Sept. 1917. \R.V. de Salvaza." [pr.]; “1918-1” [pr.]; "NHMUK 013587292" [pr.]. Pinned, distiflagellomere of both antennae missing (BMNH). 
Additional material examined. CAMBODIA: Siem Reap, Angkor Thom, 5 Feb. 2003, S. De Greef leg., by hand (2^, one third instar nymph, RBINS); same locality, 2 Jun.-12 Jul. 2003, D.R. Jump leg., by net $(2 \hat{\jmath}, 2$, , one fifth instar nymph, RBINS); same locality, collector and method, Aug. 2003 (2ર̂, 5 ㅇ, RBINS).

Distribution. CAMBODIA: Siem Reap (Angkor Thom) $\left(13^{\circ} 26^{\prime} 28.8^{\prime \prime} \mathrm{N}, 103^{\circ} 51^{\prime} 32.2^{\prime \prime} \mathrm{E}\right)$ [new record]; LAOS: Luang Prabang $\left(19^{\circ} 53^{\prime} 19.5^{\prime \prime} \mathrm{N}, 102^{\circ} 8^{\prime} 9.2^{\prime \prime} \mathrm{E}\right)$ (Fig. 54).

Comparative notes. Ectinoderus confragosus comb. n. has a long antennal scape and weakly developed anterolateral pronotal angles, and the m-cu cross vein in the corium is absent, therefore it should be placed in the genus Ectinoderus. Photographs of type material (Figs 22-27) and of non-types of each sex (Figs 28-33; the resin coating has been removed) are provided here to facilitate the identification of this species. This species is clearly distinct among the species within the genus in its overall bicoloured abdominal connexivum, in which segments II to V are darkbrown with basal fourth light-coloured, and segments VI and VII are homogeneously yellowish-brown. A similar colour pattern is recorded in E. caedens Miller, 1958 from New Guinea, but in this species the laterotergites of abdominal segments II to $\mathrm{V}$ are completely blackish, and those of segments VI and VII are light-yellowish-brown. Ectinoderus caedens also has a different colour pattern on the pronotum (light-yellowish-brown with a wide, blackish suffusion posteriorly vs. generally dark-brown in E. confragosus comb. n.) and the legs (generally blackish, coxae, trochanters and bases of femora light-yellowish-brown vs. generally brownish with light-coloured patterns in $E$. confragosus comb. n.), and its pronotum expands into two angular lobes posteriorly (vs. rounded in E. confragosus comb. n.).

Ectinoderus confragosus comb. n. resembles the Myanmar species E. exortivus Distant, 1903 in general appearance, but clearly differs from the latter by the completely different colour patterns on its legs (mid and hind femora dark-brown to blackish-brown, each with two subapical, light-yellowish-brown spots forming an incomplete annulus, mid and hind tibiae blackish-brown in E. confragosus comb. n. vs. mid and hind femora brown to dark-brown on basal two thirds, yellowish-brown on apical third, mid and hind tibiae yellowish-brown on basal fourth, blackish-brown on apical three fourths in E. exortivus) and the connexivum (segments II to V bicolorous, VI and VII uniformly yellowish-brown in E. confragosus comb. n. vs. all segments bicolorous in E. exortivus).

ACKNOWLEDGEMENTS. We are grateful to M.D. Webb $(\mathrm{BMNH})$ for correcting the manuscript and for his kind help during our examination of specimens of Reduviidae. We thank J. Constant (RBINS) for the loan of specimens, and H. Viljanen, P. Malinen (MZH) and R. Douglas (OUMNH) for information and photographs of types. We are indebted to P. Švácha (Institute of Entomology, Czech Academy of Sciences, České Budějovice) and two anonymous reviewers for their helpful comments and critical reading of the manuscript. This work was supported by a grant from the National Natural Science Foundation of China (No. 31730086).

\section{REFERENCES}

AmBrose D.P. 2006: A checklist of Indian assassin bugs (Insecta: Hemiptera: Reduviidae) with taxonomic status, distribution and diagnostic morphological characteristics. - Zoos Print $J$. 21: $2388-2406$.

Амyot C.J.-B. \& Serville J.-G.A. 1843: Histoire Naturelle des Insectes. Hémiptères. Librairie encyclopédique de Roret, Paris, xxxvi +675 pp., 12 pls.

Bergroth E. 1913: New genera and species of Reduviidae from Borneo. - Sarawak Mus. J. 3: 25-38.

CAI W., Chou Y. \& Lu J. 1994: The morphology, postembryonic development and evolution of stridulitra in Reduviidae with special reference to their taxonomic importance (Heteroptera: Reduvioidea). - Entomol. Sin. 1: 1-16.

CHINA W.E. 1940: Key to the subfamilies and genera of Chinese Reduviidae with descriptions of new genera and species. Lingnan Sci. J. 19: 205-255.

DAVIS N.T. 1969: Contribution to the morphology and phylogeny of the Reduvioidea. Part IV. The Harpactoroid Complex. Ann. Entomol. Soc. Am. 62: 74-94.

Distant W.L. 1903-1904: The Fauna of British India, Including Ceylon and Burma. Rhynchota. - Vol. II. (Heteroptera). Taylor \& Francis, London, 503 pp. [pp. 1-242: 1903; pp. 243-503: 1904].

Distant W.L. 1911: Rhynchota Indica (Heteroptera) - Entomologist 44: 104-107.

Distant W.L. 1919a: The Heteroptera of Indo-China. — Entomologist 52: 207-211.

Distant W.L. 1919b: The Heteroptera of Indo-China. - Entomologist 52: 243-246.

HerRICH-SCHÄFFER G.A.W. 1849-1853: Die Wanzenartigen Insecten. 9. Lotzbeck, Nürnberg, 348 pp. [pp. 1-44: 1849; pp. 45-240: 1850; pp. 241-288: 1851; pp. 289-348: 1853].

HeRRICH-SCHÄFFER G.A.W. 1853: Alphabetisch-synonymisches Verzeichniss der wanzenartigen Insecten. Manz, Regensberg, 210 pp.

HoffmanN W.E. 1944: Catalogue of Reduviidae of China. Lingnan Univ. Sci. Bull. 10: 1-80.

Hsiao T.-Y. \& Ren S.-Z. 1981: Reduviidae. In Hsiao T.-Y., Ren S.-Z., Zheng L.-Y., Jing X.-L., Zou H.-G. \& Liu S.-L. (eds): A Handbook for the Determination of the Chinese Hemiptera Heteroptera (II). Science Press, Beijing, pp. 390-538 [in Chinese, English abstr.].

KERZHNER I.M. 1992: Nomenclatural and bibliographic corrections to J. Maldonado Capriles (1990) "Systematic catalogue of the Reduviidae of the World (Insecta: Heteroptera)". — Zoosyst. Rossica 1: 46-60.

Lethierry L. \& Severin G. 1896: Catalogue Général des Hémiptères. Tome III. Hétéroptères, Tingidae, Phymatidae, Aradidae, Hebridae, Hydrometridae, Henicocephalidae, Reduviidae, Saldidae, Apophilidae, Ceratocombidae, Cimicidae, Anthocoridae. Friedländer \& Fils, Berlin, 275 pp.

Maldonado-CAPRILES J. 1990: Systematic Catalogue of the Reduviidae of the World (Insecta: Heteroptera). University of Puerto Rico (special edition of Caribbean Journal of Science), Mayagüez, $\mathrm{x}+694 \mathrm{pp}$.

Miller N.C.E. 1938: Function of the 'fossula spongiosa' or spongy furrow in Reduviidae (Rhynchota). - Nature 141: 749-750.

MilLER N.C.E. 1942: On the structure of the legs in Reduviidae (Rhynchota). - Proc. R. Entomol. Soc. Lond. (A) 17: 49-58.

MilLER N.C.E. 1954: New genera and species of Reduviidae (Hemiptera - Heteroptera) from the Indo-Australian Region. Treubia 22: 407-452. 
MiLler N.C.E. 1956: The Biology of the Heteroptera. Leonard Hill, London, $x+162$ pp., 5 pls.

MiLLER N.C.E. 1958: Results of the Archbold expeditions. On the Reduviidae of New Guinea and adjacent islands (Hemiptera Heteroptera). Part 1. - Nova Guinea 9: 33-143.

Miller N.C.E. 1971: The Biology of the Heteroptera. 2nd (rev.) ed. E.W. Classey, London, xiii + 206 pp., 5 pls.

Putshoov P.V. \& Putshkov V.G. 1996: Family Reduviidae Latreille, 1807, assassin bugs. In Aukema B. \& Rieger C. (eds): Catalogue of the Heteroptera of the Palaearctic Region, Vol. 2, Cimicomorpha I. The Netherlands Entomological Society, Amsterdam, pp. 148-265.

RoEPKE W. 1932: Über "Harzwanzen" von Sumatra und Java. Misc. Zool. Sumatrana 68: 1-5.

Schun R.T. \& Slater J.A. 1995: True Bugs of the World (Hemiptera: Heteroptera). Cornell University Press, Ithaca and London, $\mathrm{xii}+337 \mathrm{pp}$.

Schun R.T. \& Weirauch C. 2020: True Bugs of the World (Hemiptera: Heteroptera). 2nd ed. Siri Scientific Press, Manchester, $768 \mathrm{pp} ., 32 \mathrm{pls}$.

Schun R.T., Weirauch C. \& Wheeler W.C. 2009: Phylogenetic relationships within the Cimicomorpha (Hemiptera: Heteroptera): a total-evidence analysis. - Syst. Entomol. 34: 15-48.

Shorthouse D.P. 2010: SimpleMappr, an Online Tool to Produce Publication-Quality Point Maps. URL: https://www.simplemappr.net (last accessed 3 Apr. 2021).

STÅL C. 1859: Nova methodus Reduvina (Burm.) disponendi. Dtsch. Entomol. Z. 3: 328.

STÅL C. 1865: Hemiptera Africana. Tomus Tertius. Norstedtiana, Stockholm, $200 \mathrm{pp}$.

STÅL C. 1866: Analecta hemipterologica. - Dtsch. Entomol. Z. 10: $151-172$.

STÅL C. 1867: Contribution to the knowledge of Reduviidae. Öfvers. K. Vetensk.-Akad. Förh. 23 [1866]: 235-302 [in Latin, Swedish title].
STÅL C. 1871: Hemiptera insularum Philippinarum. - Contribution to the Hemipteran fauna of the Philippines Islands. Öfvers. K. Vetensk.-Akad. Förh. 27 [1870]: 607-776 [in Swedish and Latin].

STÅL C. 1874: Enumeratio Hemipterorum. Contribution to a list of the hitherto known Hemiptera, with systematic notes. 4. K. Sven. Vetensk. Akad. Handl. (N.F.) 12: 1-186 [in Latin, with title in Latin and Swedish].

WALKer F. 1873a: Catalogue of the Specimens of Hemiptera Heteroptera in the Collection of the British Museum. Part VII. British Museum (Natural History), London, 213 pp.

WALKER F. 1873b: Catalogue of the Specimens of Hemiptera Heteroptera in the Collection of the British Museum. Part VIII. British Museum (Natural History), London, 220 pp.

WeIRAuCh C. 2008a: Cladistic analysis of Reduviidae (Heteroptera: Cimicomorpha) based on morphological characters. Syst. Entomol. 33: 229-274.

WeIRAUCH C. 2008b: From four- to three-segmented labium in Reduviidae (Hemiptera: Heteroptera). — Acta Entomol. Mus. Nat. Prag. 48: 331-344.

WeSTwOOD J.O. 1843: Descriptions of some new exotic Reduviidae of large size. - Ann. Mag. Nat. Hist. 11: 466.

WeSTwOOD J.O. 1845: Descriptions of some species of exotic heteropterous Hemiptera. - Trans. Entomol. Soc. 4: 119-122, pl. VII.

WheELER R.G. 1912: On the dates of the publications of the Entomological Society of London. - Trans. Entomol. Soc. 59: 750-767.

Zhang J., Weirauch C., Zhang G. \& Forero D. 2016: Molecular phylogeny of Harpactorinae and Bactrodinae uncovers complex evolution of sticky trap predation in assassin bugs (Heteroptera: Reduviidae). — Cladistics 32: 538-554.

Received April 24, 2021; revised and accepted July 13, 2021 Published online August 6, 2021 